\title{
DENTRO DE UN PROCESO MUNDIAL. LOS INICIOS DE LA ACTIVIDAD TURÍSTICA EN EL PERÚ (1800-1850)
}

\author{
IN A WORLD PROCESS. THE BEGINNINGS OF THE TOURIST \\ ACTIVITY IN PERU (1800-1850)
}

Fernando Armas Asín

Universidad de San Martín de Porres, Perú.

\section{RESUMEN}

Se indaga los orígenes del turismo en el Perú durante la primera mitad del siglo XIX, en un contexto que muestra la llegada de un creciente número de viajeros extranjeros, y del interés acerca del Perú que despiertan diversas publicaciones en Europa. Siguiendo a un conjunto de relatos de viajeros, se establece los lugares de atracción para los visitantes extranjeros, la situación de los hospedajes y los caminos, así como la comida a la que tenían acceso. Se plantea que la situación de este turismo embrionario era el mismo que existía en Europa, previo al surgimiento de la sociedad de consumo y de masas.

Palabras clave: Viajero, tambo, fonda, chupe.

\begin{abstract}
The article investigates the origins of tourism in Peru during the first half of the nineteenth century, in a context of arrival of an increasing number of foreign travelers as well as interest on the Peru that arouse various publications in Europe. Following a series of stories of travelers, it establishes the places of attraction for foreign visitors and what was the situation of the lodges, roads as well as the food that were accessible. It argues that the situation of this embryonic tourism was the same that existed in Europe before the emergence of the consumer society and mass.
\end{abstract}

Keywords: Traveller, tambo, inn, chupe 


\section{Introducción}

La llegada del siglo XIX supuso para el mundo occidental, en particular para Europa, una época de grandes transformaciones. La revolución industrial, que recorre toda la centuria permite no solo que la actividad económica se centre en la industria sino que además ella vaya acompañada de una revolución en las tecnologías, particularmente las ligadas a los medios de transportes y comunicaciones: el ferrocarril, la navegación a vapor, los telégrafos, que integra a los diferentes países y estos al mundo. Las sociedades devienen urbanas y partes de una economía que es ahora planetaria e integrada. Lo cual, permite el desarrollo, dentro de las urbes y los países, de un vasto sector de servicios: los propios de los transportes a vapor y de comunicaciones, tanto como luego los servicios de agua, alumbrado, financieros, seguros, etc. En ese escenario no solo se amplía el sector social de la burguesía sino que además ella muestra sus nuevos gustos e intereses.

Lo narrado está en la base de la formación de los elementos típicos de la actividad del turismo: los viajes por simple recreación y descanso, que antes lo solía efectuar la aristocracia se hace extensivo, y con sus propias peculiaridades, a la burguesía, que dispone de tiempo en el año para «ir de vacaciones». En Francia o en Gran Bretaña aparecen los balnearios como destinos obligados para el descanso y alrededor de ellos se crea una infraestructura para hacerlos posibles: líneas férreas, hoteles, restaurantes.

Aparecen, también, otros lugares de destinos para la excursión o recreación. Por ejemplo, hacia 1840 había un servicio de barcos para pasear a las personas por el río Támesis y era tan popular que incluso había un periódico para cubrir esta actividad, Steamboat Excursion Guide. En esta época predominan los llamados hoteles de viajeros, que ofrecen un servicio mínimo de calidad con muchas deficiencias añadidas (los hoteles empiezan a evolucionar recién en la segunda parte del siglo XIX). Pero el camino va en ascenso y en 1829 Baedeker publica una guía para recorrer el Rhin, con información útil de alojamientos, gastronomía, lugares de interés. Aparece el embrión de la moderna guía de turismo, superando las clásicas guías para viajeros y comerciantes. De alguna manera se hace presente el moderno operador turístico, pues en esta guía se ofrecían soluciones orientadas a los intereses del turista. Luego, a partir de la década de 1840, en Gran Bretaña, aparecen los primeros rasgos de lo que denominaríamos agencias de viajes (Khatchikian, 2000, pp. 136-147). Sin embargo, hay que recordarlo, todavía el beneficiado es un miembro de la capa más alta o de ciertas capas medias de la sociedad.

Mientras estos cambios se producen en Europa entre las décadas de 1800 y 1840, en América hispánica y el Perú ocurre el proceso de independencia del dominio español. Con esa independencia, que en nuestro caso aconteció en 1821, se dieron cambios en el orden económico y social, debido a la apertura comercial y social del Perú al mundo, en particular a los países que se estaban industrializando, y con ello se hizo evidente la afluencia cada vez mayor de extranjeros. Muchos se afincaron en los puertos -el Callao, Quilca, Arica, Pisco, Paita $-\mathrm{u}$ otras ciudades importantes, integrando colonias -ingleses, franceses, norteamericanos- dedicadas al comercio y generando una simbiosis cultural particular.

El Perú se volvió una atracción poderosa para los extranjeros. En sus países de origen, donde desde antaño el Perú estaba envuelto entre lo misterioso y exótico, ahora, con la apertura mercantil y la velocidad de las comunicaciones, se reforzaba ese significado. Era parte de la atracción que provocaba en los europeos la 
periferia del mundo. Si en el siglo XVIII se editaron 3 mil testimonios sobre el mundo, en el siglo XIX fueron 6 mil. Sobre el Perú, a finales de 1820 fueron publicados en Europa, como se verá, los testimonios de Basil Hall (1825) y William Benet Stevenson (1826-1828). Luego los de Flora Tristán (1838), René Lesson (1839) y Alcides d’Orbigny (1839). Luego en 1840 los de Lafond de Lucy (Tauzin-Castellanos, 2015, pp. 44-45).

Sostenemos que al igual que en otros procesos políticos, económicos y sociales, el desarrollo de los elementos de lo que hoy denominamos la actividad turística se dio paralelamente a lo acontecido en Europa o Estados Unidos. Contra lo que tradicionalmente se ha supuesto, que mientras el turismo se empieza a desarrollar en Europa en esta parte del mundo no existe ni rastro o asomo de él, creemos que más bien este se fue dando en forma asombrosa, con elementos comparables del fenómeno, que debieran llevarnos a análisis comprensibles sobre los efectos simúltaneos y múltiples en el mundo del siglo XIX.

En este artículo, vamos pues a estudiar el turismo como práctica económica y social en la primera mitad del siglo XIX. Nos centraremos en los relatos de los diversos extranjeros que fueron arribando al país y fueron delineando no solo una cierta mirada sobre el Perú, sino específicamente ciertos lugares de interés, sea en Lima, sea en las diferentes regiones. Los relatos, además, nos deben ayudar a delimitar cómo era la oferta de hospedaje en el Perú, la oferta culinaria que se le ofrecía al visitante, así como la infraestructura de transporte existente. Todo lo cual nos debe ayudar a entender de qué desarrollo del turismo hablamos cuándo nos referimos al existente en aquella época.

\section{Las primeras miradas del turista: la fijación de Lima}

Hay que observar que estos extranjeros de paso por el Perú, o bien en misiones militares -mayormente navales- o bien por razones comerciales, se vuelven turistas en tanto que más allá de sus actividades, así como un hombre de negocios moderno, aprovechan de su viaje para visitar ciertos lugares de interés que no tiene mayormente que ver con la razón de sus actividades. Se vuelven observadores, consumidores de lo que se les ofrece a sus ojos, o ellos mismos lo buscan y lo convierten en un lugar de interés. Muchas veces, sus incursiones sirven para comprobar que existe ese lugar, ese objeto, como atractivo para su mirada foránea. Aunque no hay todavía una idea clara sobre el Perú como conjunto y lo que representa, en estas huellas sin embargo se puede apreciar lo que en ese momento está naciendo.

Por ejemplo, Alexandre von Humboldt, ese naturalista alemán que recorrió Sudamérica a fines de la época colonial y visitó el norte del Perú en 1802, nos plantea los intereses de un científico interesado en las condiciones naturales del país, pero también atraído por su pasado, por las antigüedades peruanas.

Entra al nororiente peruano desde el Ecuador y luego pasa a Cajamarca en setiembre de 1802 y recorre la costa hasta Lima en el mes de octubre. Nos habla de la naturaleza que va observando, pero también de los restos del viejo reino del Chimor y del pasado inca de la región. Es una mirada arqueológica la suya, pero también se nota un interés por entender a los hombres del lugar y cómo valoran el patrimonio que poseen. Por ejemplo, en Cajamarca recorre los Baños del Inca y otros conjuntos arqueológicos guiado por gente del lugar: «Nos enseñaron escaleras talladas en roca y lo que llaman el lavadero de los pies del Inca» (Humboldt, 
2004, p. 145). «Enséñase también a los viajeros la pared en que se hizo una seña, para indicar la altura hasta la cual se comprometía a llenar de oro la habitación» (Humboldt 2004, p. 146). Existe pues, una conciencia histórica en los lugareños y un interés por mostrar. Al parecer, cuando los foráneos llegaban a Cajamarca y buscaban conocer estos lugares siempre había gente dispuesta a llevarlos: «En la capilla de la prisión municipal, construida, como ya dije, sobre las ruinas del palacio de los incas, los guías enseñan a los crédulos una piedra teñida por una 'mancha de sangre indeleble'». Es la sangre del inca. «El hijo del cacique Astorpilco, agradable muchacho de 17 años, que me guiaba a través de las ruinas de su casa paterna, del palacio de sus antepasados, había poblado su imaginación de seductoras imágenes en medio de su extrema pobreza» (Humboldt, 2004, pp. 147-149).

También Lima, desde hacía mucho tiempo atrás -recuérdese a los distintos viajeros del siglo XVIII, como Frézier o Dombey-, despertaba ese interés por recorrerla y conocerla desde el momento que a ella se llegaba. El viajero y comerciante francés Julián Mellet -que publicó su libro sobre sus recorridos por América del Sur en París en 1824, en la editorial Chez Maisson et fils- recorre Lima en 1815, sus calles, la Plaza, va al Rímac, a la Alameda, la Plaza de Acho, habla sobre las mujeres, sobre la saya y el manto, almuerza con algunas de ellas en una picantería, luego va a una fonda y se sorprende de sus habilidades para la comida y se admira de la chicha. Habla de que a dos leguas al sur de Lima está Buena Vista o Chorrillos, donde en verano los limeños particularmente- se trasladan a tomar baños y se dedican a las diversiones y los juegos. Dice que hay muchos «hoteles, cafés y juegos» (Mellet, 1971, pp. 83-90). Dos años después, en 1817, el noble y marino francés Camille de Roquefeuil, de paso por el puerto del Callao y nuestras costas, recorre la universidad de San Marcos, la Casa de la Moneda, las iglesias, observa las fiestas religiosas -Domingo de Ramos, Pascua- y los lugares de diversión existentes para los habitantes de la ciudad: la Alameda del Callao, el Teatro, las corridas de toros y las peleas de gallos en el Coliseo, donde muchos asisten sin mayor distinción de clases. Se pasea por la Alameda Nueva, en el Rímac y hace una excursión al sur y visita Miraflores, Barranco y Lurín, pasando por el Sitio Arqueológico de Pachacámac, que lo describe con detalle (Roquefeuil, 1971, pp. 131-138).

Así pues, Lima y sus atractivos se van dibujando a los ojos de los visitantes. Como le ocurrió al gran marino y viajero inglés Basil Hall, quien publicó las impresiones de sus misiones por el mundo en varias obras, siendo la del Perú, Chile y México impresa en 1824, en dos volúmenes. Ejerció tanta influencia sobre el público lector que en 1825 se hizo una segunda edición y luego esta obra fue traducida al francés y al alemán. En parte de los extractos de su diario habla de Lima en 1821, de sus mujeres, la saya y el manto, de las iglesias y del teatro como lugares de visita. Nos narra su estancia en Miraflores, buscando los ranchos apacibles donde la elite limeña iba a descansar en verano, pero nota que no hay ningún bañista en la playa y los bancos para sentarse de las afueras de las casas-ranchos, así como las glorietas y otros lugares de descanso, estan vacíos. Es, sin duda, debido a la guerra de independencia. Pero argumenta que «ningún viajero, dicen, entró nunca a una gran ciudad sin sufrir desencantos, y la capital del Perú no es una excepción a esta regla» (Hall, 1971, pp. 195-268). El marino inglés Gilbert F. Mathison, por su lado, en un extracto de su libro de viajes -aparecido en Londres en 1825- narra sus impresiones de esta ciudad que la recorrió entre abril y mayo de 1822, también en los días de la independencia. Visitó el cementerio, los alrededores de la ciudad, fue a los baños públicos, tal vez refiriéndose a Miraflores, un lugar con treinta casas de paredes de barro y techo plano de cañas y con treinta cabañas al final del acantilado que se nutrían del agua de un manantial de un cerro cercano. Visitó el 
Sitio Arqueológico de Pachacámac y se maravilló de su estado de conservación. Visitó también Chorrillos, «la Brigthon» de Lima, lugar muy concurrido en verano, de 200 o 300 casas, la mayor parte habitada por indios todo el año (Mathison, 1971, pp. 282-313).

Como él, penetrante se nos muestra William Bennet Stevenson, con sus impresiones ubicadas entre 1804 y 1821. Las publicó en su monumental obra en tres volúmenes, Historical and descriptive narrative of tewnty years' residence in South America (Liverpool 1825, 2 vols.; London: 1829, 3 vols.), haciendo una descripción de Lima, su valle, las temperaturas y la humedad.

Hizo un análisis de las casas de la ciudad, de sus iglesias, conventos y parroquias, de la Catedral, del Cabildo, los hospitales, la Inquisición, la Casa de la Moneda, para luego apreciar a sus gentes en sus diversas etnias, observar a las mujeres, a la tradición de la saya y el manto. Aunque tal vez lo más agudo fue describir las diversiones cotidianas de sus habitantes: la Plaza de Toros de Acho, con más de «veinte mil» personas participando de esta actividad. $\mathrm{O}$ el Teatro, donde se congregaba también la multitud, o las peleas de gallos en el Coliseo. O los paseos, como el camino de Lima al Callao o los lugares creados por el Virrey Amat en el siglo XVIII: la Nueva Alameda, de una milla de largo, arbolada, con camino para carruajes y asientos en los costados, a la cual concurrían, en las tardes de los domingos y feriados, el público en más de 300 carruajes, sobre todo con mujeres, pues los hombres preferían montar a caballo durante el paseo. Finalmente, menciona que el paseo de lomas o de Amancaes se hace los días de San Juan y San Pedro, cuando los narcisos amarillos cubren las lomas y el entretenimiento mayor es beber leche y comer dulces y crustáceos (Stevenson, 1971, pp. 119-175).

Menciona además, una diversión favorita de los sectores altos limeños, como son las casas de juego, que están prohibidas por el gobierno, pero que en las casas de campo de la nobleza se practica e incluso en los baños de Miraflores, Chorrillos y Lurín, congregando a veces a gentes de condiciones sociales diferentes, «se confunden indiscriminadamente, el maestro, y el esclavo, el marqués, el conde, el mecánico y el buhonero». Justamente observando cómo va a Chorrillos mucha gente por los juegos, destaca que algunos se animan y bajan al mar, con lo cual remarca la existencia de una fuerte atracción de los baños de mar como movilizadora para una fracción de la sociedad limeña. Refiere, que algunos buscando continuar con los juegos, prefieren irse más lejos, a Lurín, pues «la distancia impide la concurrencia a estos lugares de las clases más bajas de la sociedad» (Stevenson, 1971, pp. 165-174).

De esta manera en estos años, con la concurrencia más asidua de extranjeros -resultado del aumento del comercio mundial y de los cambios políticos- que dan a conocer reiteradamente sus pareceres, podemos darnos cuenta como poco a poco se van delimitando dos ejes muy claros sobre una visión de Lima. Por un lado el que describe a la ciudad y sus gentes: recorre los edificios, el Palacio, el Teatro, las iglesias, el Cabildo, la Casa de la Moneda, o el Cementerio; así como observa a los habitantes, en especial a las mujeres limeñas y casi siempre habla de su vestimenta: de la saya y el manto. Y por otro lado, el que observa y visita los espacios de diversión de los limeños: un espacio interior de la ciudad que está en el Rímac -la Alameda, la Plaza de Acho, el Paseo de Aguas- al cual se le agrega el Coliseo de Gallos o el Teatro; y otro exterior y novedoso: Miraflores, Chorrillos y Lurín, lugares de esparcimiento y descanso. 


\section{Los baños de Chorrillos}

La promoción de ciertos lugares que quedaron al alcance de las manos de todos -convirtiéndose en un acontecimiento público- pero donde el sector más alto determinó inicialmente su viabilidad y su moda, es un fenómeno europeo que va dándose en estos años, siendo el ferrocarril el vehiculizador de su desarrollo. Así, a partir de 1830, en Europa aparecen diversos balnearios que se convirtieron en lugares de moda para la burguesía, tanto que después se convertirían en destinos para las vacaciones del gran público (Khatchikian, 2000; Urry, 2004). En 1848 había un tren expreso publicitado, de París a Dieppe en una hora, para ir al mar.

De esta manera, existe un cambio en el atractivo que ejerce el mar, que había sido considerado un lugar para los pescadores y otros lugareños, y en donde exponerse a los rayos solares era considerado la mejor constatación del trabajo arduo de las clases inferiores. «La exposición al sol no se consideraba elegante pues se suponía reservada a los aldeanos y a la gente de condición social inferior que se veía obligada a realizar sus labores al aire libre» (Khatchikian, 2000, p. 141). Sin embargo, desde el siglo XVIII se habían puesto de moda los baños de mar, adquiriendo una connotación terapéutica debido a sus supuestas capacidades curativas, mejor que los baños termales clásicos. El baño se tomaba como cura e inicialmente no era cuestión de nadar, jugar en la arena ni mucho menos tomar baños de sol. Sin embargo, pronto esto cambiaría (Khatchikian, 2000; Urry, 2004; Walton, 1983). Así, el turista aristocrático como el burgués rentista -que invertía celosamente sus ingresos en las diversiones- con las estaciones del año se movilizaba: en invierno a ciertos lugares de recreo por horas o días, a las haciendas o a lugares de descanso o distracción; luego en verano a las estaciones termales o al mar.

En el caso de Chorrillos, y en menor medida Miraflores, se convirtió en un lugar de movilización para las clases altas limeñas. Lugar de atracción, de visita, no solamente como refugio para poder jugar -como Lurín- sino para poder bañarse, es decir, una atracción natural en sí, que obliga a ciertas familias limeñas a buscarlo en verano. Chorrillos llama la atención de los extranjeros: hay en la obra del comerciante P. Campbell Scarlett, South America and The Pacific (London, 1838), tomo II, dos láminas preciosas donde se aprecia el asalto a un grupo de visitantes a este sitio y su regreso a Lima casi desnudos, lo cual indica por un lado su atractivo, pero también es una denuncia de la inseguridad que prima en los caminos, entre chacras y bandoleros. Estuvo él en Lima hacia 1835.

Así, cuando finalmente, llegamos a los grandes viajeros que describieron con lujo de detalles los lugares limeños de atracción que visitaron con frecuencia, tenemos una idea y una imagen ya inamovible de la capital y sus alrededores. Por ejemplo, en el caso de Gabriel Lafond de Lurcy. La obra escrita y publicada sobre América española de este viajero francés, en 1843, veintiún años después y en ocho volúmenes, causó un gran impacto en el público francés. Nos habla de Lima, del barrio de San Lázaro, del Palacio, el Teatro, las iglesias, el Cabildo, entre otros edificios. Como estaba hospedado en casa de la señora Rosa Salazar, de buena familia, cerca de la Plaza, escucha de las peleas de gallos, y va a ellas, como luego a la Plaza de Toros.

Se siente incómodo con estas diversiones, pero por sobre todo le atraen las mujeres de Lima: las tapadas y su sensualidad. De hecho, cual dandy, con un compañero de aventuras, a la salida de la Plaza de Toros se hace amigo de un par de ellas, con las que va a una picantería a comer cancha, un «picante» y beber chicha. 
Aunque comer con las manos no le agrada, tanto como estar en ese lugar o ingerir ese plato, se lo pasa bien y de hecho se sorprende de que las chicas limeñas coman tanto y con sabores tan fuertes, pues al día siguiente se encuentran y comen tamales y chicharrones con facilidad (Lafond, 1971). También, nos habla de los paseos limeños: de la Alameda Grande, del Callao a Lima; de la Nueva Alameda, con sus carruajes y sus distintos baños al final de ella; de la Alameda Vieja y del inconcluso Paseo de Aguas.

Invitado por ciertas familias limeñas -Cortez, Salazar, Izcue- asiste a un paseo en Amancaes. Se maravilla con el tiempo de lomas, pues quebradas y cerros se tiñen de verdor y de estos narcisos amarillos. Con estas familias pasó ocho dias allí, durmiendo en unas cabañas diseñadas para la ocasión, asistiendo en las mañanas a recoger flores, a beber leche que los pastores ofrecían -pues justo coincidía ese tiempo del año con que los pastores movían sus ganados a las inmediaciones para aprovechar las lomas como forraje-, luego a almorzar, para, en las tardes, dedicarse a los bailes, las tertulias o a los juegos de azar. Se acostaban sobre unos colchones puestos sobre el piso o sobre unos tablones, «bebiendo, bailando, cantando día y noche en la más completa libertad» (Lafond 1971, pp. 130-131). Se regresa a la ciudad, anotó, cuando cae la neblina, adornados con flores amarillas en el cabello, en los sombreros, o adornando sus carruajes o a los animales. «Esto recuerda mucho el gusto de los parisienses por sus primeras lilas» (Lafond, 1971, p. 131).

Luego nos refiere de los baños de mar, de Miraflores, formado por cabañas y ranchos, y sobre todo de Chorrillos, más importante, con sus ranchos, donde conviven al lado de una iglesia, casas de indios y de los propietarios de Lima.

La gente va a descansar, a jugar, y a tener una vida apartada del mundanal ruido. Bañarse es la mayor distracción, bajando por un barranco, existiendo en la playa cabañas que se alquilan para cambiarse y hay indios que conducen a las damas entre el oleaje. Luego se sube a pie, aunque algunas damas lo hacen en asnos. En las noches se disparan cohetes, y hay mucho juego en las casas. Lurín es otro lugar de juego, muy apartado de Lima, «su distancia de la ciudad impide que las clases inferiores se presenten» y así «toda persona con la cara un poco blanca y los cabellos no muy crespos» puede presentarse y jugar (Lafond, 1971, p. 132).

De la misma manera Robert Proctor, cuya obra sobre el Perú fue publicada en Londres en 1825, participa de esta imagen ya asumida. En sus recuerdos de manera sencilla se describe Lima, sus edificios, el Palacio, iglesias y la Casa de la Moneda, mencionando un cierto Hotel de Francia, que fue acondicionado para la llegada del libertador Simón Bolívar; para luego hablar de las mujeres, la saya y el manto, de las costumbres, de la comida que preparan -el chupe y la olla de garbanzos o puchero- o los paseos que hacen luego a la Alameda Nueva, o al puente. También nos habla de su visita a una función del Teatro y de otra a la Plaza de Toros. Reconoce en ambas la alta concentración de gente de muchos estratos sociales. Y por cierto, comenta de los lugares extramuros de paseo de los limeños de clase alta: Miraflores, con sus casas-huertas de «magnates» que descansan allí en verano y sobre todo de Chorrillos, donde los indios les alquilan unas casas o ranchos, de arcilla y techo de caña, con una sala mirando el mar y tres o dos dormitorios interiores, mientras ellos viven a sus costados en humildes cabañas. Las familias limeñas, una vez alquiladas estas casas, llevan de Lima sus enseres y sus vinos, para así gozar de la brisa marina, de los baños y comer pescado. Durante esas semanas las limeñas bajan por el barranco hasta la playa, se cambian en unas cabañitas de caña enyesadas que existen 
entre las rocas y van acompañadas por indios hasta el mar. Se permanece en el agua de media hora a una hora, a veces conversando con amigos, para luego en la noche dedicarse a cantar y bailar con guitarra, alegremente. También, finalmente, nos habla de que muchas veces fue a Amancaes y se encontró con grupos sentados sobre fragmentos de rocas o bailando al son del arpa o cantando con guitarra. Menciona que como los indios mueven sus ganados a las lomas, la gente los visita en sus cabañas y les compran leche y queso (Proctor, 1971).

No siempre, empero, hay estas descripciones amables de la ciudad o que el visitante se sienta atraído por lugares de interés que se le ofrece. El marino francés R. P. Lesson, por ejemplo, que publicó varias obras, una de las cuales (1839) trae noticias sobre el Perú, fue muy crítico de los limeños, particularmente de la vida religiosa y en general tuvo una apreciación negativa de las mujeres, las cuales, según él estaban llevadas por la pasión y los bajos escrúpulos (Lesson, 1971, pp. 339-401).

\section{Dibujando el Perú y sus lugares de interés}

Pero, así como sobre Lima, por las obvias misiones y contactos comerciales, se dibuja una geografía de su atractivo; también sobre ciertas partes del país se empieza a realizar lo mismo. Hemos visto a Humboldt interesarse por Cajamarca y sus baños. Proctor, por su lado, reconoce la importancia arqueológica de la costa norte -Lambayeque, La Libertad-. En su viaje por Huanchaco y Trujillo anota que hay muchos sitios arqueológicos y que, sea por curiosidad o por avaricia, se exploran estas huacas y se encuentra gran cantidad de piezas arqueológicas (Proctor, 1971). En tal óptica, Guillermo Miller, en sus Memorias, donde recuerda sus años de servicios militares en las campañas por la independencia, trae algunas descripciones de los lugares por donde pasó, como la costa árida peruana, donde recomienda que los forasteros siempre lleven un guía, pues se perderían en los arenales (Miller, 1975). En el cap. XVI hace una descripción fina pero tradicional de Lima. Pero este esquema descriptivo, y es lo importante, con buen tino, lo amplia a otra ciudad. El capítulo XXVI está dedicado a Cuzco, donde comenta sobre sus habitantes, sus templos y algunas costumbres locales (Miller, 1975). Así pues, si bien con él se renueva esa mirada de los atractivos de Lima, también hay un interés de prolongar y conocer con dicho enfoque otros lugares. En esa línea, Samuel Haigh, en sus recuerdos de su paso por el Perú entre 1825 y 1827, anotó una descripción de Arequipa y Lima, con los mismos intereses que Miller (Haigh, 1967).

Pero, si hay que buscar en estos años de la República Temprana a un viajero apasionado por el país, este es Heinrich Witt, hombre dedicado al comercio, que al recorrer y visitar muchos lugares del Perú por razones de trabajo, aprovechó para visitar y conocer lugares que tal vez pudiera no interesar a un hombre de negocios, estableciendo una geografía turística nacional. Este alemán, vinculado a una casa comercial arequipeña, llegó al puerto arequipeño de Quilca en 1824 y luego de un arduo viaje arribó a la ciudad mistiana. La recorrió, visitando sus iglesias y reconociendo la existencia de un café francés. Varias veces en el futuro haría el recorrido entre Arequipa y Quilca, durmiendo en diversas casas de este puerto: en casa del jefe de aduanas, y de un tal Montufar, o en la del capitán del puerto, aunque en esta como en otras, sentirá la incomodidad de un delgado colchón y sobre todo de las pulgas, un mal difícil de evitar (Witt, 1992). 
Desde su residencia en Arequipa, y debido a sus negocios, realizará un viaje a Puno en 1826. Sale con sus compañeros y guías en varias mulas llevando sus baúles y colchones, deteniéndose en los tambos que existían en la ruta a Lampa: el de Apo, formado por cuatro casas y atendida por una familia, donde almorzó un chupe y dio forraje a sus mulas; o los de Palti o el de La Compuerta, donde durmieron sobre sus colchones debido a la precariedad de los lugares. Como va en viaje de negocios a veces no pasa por todos los tambos y se va a algunas estancias de amigos de su empresa, como la de Yanarico. En la ciudad de Lampa, luego de sus actividades mercantiles, asiste a la iglesia así como a las fiestas de la Concepción del 8 de diciembre de 1826, al aniversario de la batalla de Ayacucho o a las corridas de toros que se organizan. En sus viajes por Puno visita también Caracoto o Juliaca, hospedándose en el tambo de Caracoto. En 1827, luego de estar en Bolivia regresa a Arequipa, descansando en Cuevillas, entre casitas campesinas, y luego deteniéndose en el tambo de Pati (Witt, 1992).

Ese mismo año parte por mar de Quilca a Lima. En ella, describe las iglesias y conventos y otros edificios de interés. A fines de año parte hacia Arequipa pero no por mar, sino por la sierra central y sur peruana. Sale de Lima y descansa en la hacienda Punchauca, de doña María Ana Domínguez; luego descansa en la estancia de Caballeros y en el pueblo de Santa Rosa. Luego en Obrajillos, donde duerme en el suelo con sus colchones; luego en un sitio arqueológico conocido como El Diezmo y finalmente llega con su compañero de trabajo y su guía a Cerro de Pasco. Desde allí deciden ir a Huánuco, sin baúles o colchones, para visitar diversas estancias, por razones de trabajo.

Descansan en una estancia llamada de Andahuaylas, visitan Huánuco y no lo encuentran de mayor interés a pesar de recorrer algunas iglesias. Luego de estar en otros lugares regresan a Cerro de Pasco. Finalmente parten de Cerro de Pasco rumbo a Tarma, hospedándose en casa de Angelita Canal, gracias a una carta de recomendación. Como era diciembre pasearon por la ciudad, vieron iglesias y visitaron los tradicionales nacimientos, como el resto de la gente de la ciudad.

Pasaron luego a Jauja donde en un rato libre visitaron unos cerros cercanos que eran sitios arqueológicos así como también visitaron diversas estancias.

Luego, desde Huancayo, adonde llegan, deciden por curiosidad pasar por la célebre misión de Ocopa, a conocerla, aunque solo pudieron visitar sus claustros pues no estaban las autoridades -con las llaves- para que les hicieran observar la iglesia. Luego siguieron de Huancayo a Huancavelica. Allí, en esa ciudad, como siempre, se dedican a apreciar las iglesias y conventos.

Después se van a Huanta, acampando con sus colchones en distintos puntos del camino, en medio de la naturaleza, aunque luego en la ciudad de Huanta se hospedan en la casa de una señora que conocieron en este trayecto. De Huanta pasaron a Huamanga, donde se quedaron en casa de un vecino ilustre, gracias a una carta de recomendación que tenían. Aparte de efectuar la labor que los ha llevado allí, por supuesto van a observar el trabajo de los artesanos de piedra blanca y se maravillan. Van luego a visitar la pampa de La Quinua, y «en el monasterio de Santa Clara bebimos un chocolate». Parten de Huamanga rumbo al Cuzco, y a pesar de haber tambos en el camino, a veces duermen a la intemperie, pues lo prefieren a la incomodidad y 
poco aseo de estos lugares. En Talavera, cerca de Chincheros, pernoctan en casa de una persona a la que llevan una carta de recomendación, quien les proporciona chupe y un cuarto para pasar la noche. Por último, llegan a la ciudad del Cuzco, visitan las iglesias, la Compañía, Santa Catalina, llevando como siempre cartas de recomendación de amigos. Visita luego Ollantaytambo, con una carta que le entrega al párroco Zúñiga, quien le asigna a alguien para que lo pasee por el lugar arqueológico. Reconoce que el sitio «solamente es visitado por los viajeros debido a sus ruinas» (Witt, 1992, I: 179-262). Otro día en la ciudad se levanta muy temprano para visitar Sacsayhuaman; y otros le muestran la Catedral y sus joyas. En su diario anota una dilatada descripción de este edificio.

Volverá a Lima, en otro viaje de julio de 1828, haciendo una visita al sur, pasando por Pachacámac y quedándose a dormir en la posta del mismo nombre. Luego visitará Chilca, Asia y Chincha Alta (Witt, 1992).

También el norte del Perú, narrando una historia de la virgen de Huanchaco, visitando Chan Chan y la Huaca del Sol y de la Luna. En Cajamarca va a los baños termales, a los Baños del Inca. En Chota presencia las festividades religiosas del Corpus, trazando una bella descripción de esta fiesta chotana. De regreso visita en Huamachuco «unas extensas ruinas que quedan cerca» (Witt, 1992, I, pp. 343-441) y en Ancash visita también El Castillo de Chavín . En posteriores viajes, en la campiña de Arequipa, recorrerá una y otra vez el sitio natural de la Peña, una cueva en alto desde donde caía un chorro de agua y formaba una piscina, y aprovechando otro viaje a Lima, en 1843, visita el balneario de Chorrillos (Witt, 1992).

Así pues con Witt, en estos años de la república temprana, podemos apreciar que de la mano de los extranjeros que recorren el país, y también de otros foráneos -incluyendo a limeños que por negocios u otras necesidades viajan- así como de la propia gente del lugar, hay un interés por ciertos lugares que hoy son centro de atracción y que ya lo son en esos años: ciertos edificios, ciertas fiestas o tradiciones regionales; así como lugares arqueológicos o sitios naturales. Claramente cada región tiene su atractivo, a pesar de que los visitantes son escasos y no hay nada estructurado en los lugares del interior del país para este visitante de paso.

\section{La construcción del tour del Perú}

El vizconde Eugene de Sartiges, secretario de la embajada francesa en Río de Janeiro, desembarca en Islay en 1834 -nuevo puerto sureño que reemplaza al de Quilca- en vísperas de una guerra civil, y recorre Arequipa, Puno, Cuzco, publicando luego sus apuntes de viaje con un catálogo de presentación que lo llama de «curiosidad» (De Sartigues - Botmiliau, 1947, p. 7). De 22 años viaja, según sus anotaciones, por la monotonía que le da lo ya conocido, acaso el aburrimiento y la necesidad del alejamiento personal. Es observador este vizconde de finos modales, según Flora Tristán -que lo conoció y trató en Arequipa- viéndolo tomar apuntes constantemente. Era un viajero romántico en tierras ignotas, y sus libretas darían pie luego a un relato de viajero típico del siglo XIX, apareciendo 17 años después con un seudónimo -E. S. de Lavandais- en la Revue des Deux Mondes en 1851, de París, en tres entregas sucesivas entre enero y junio de ese año. 
Su viaje debió empezar a fines de 1833 y se prolongó hasta el verano de 1835 . Procedente de Chile, este «lindo francés de blondos cabellos» como lo llama Flora Tristán, que hacía delirar a las mujeres arequipeñas, como a otras mujeres de las ciudades por donde pasaba, venía sencillamente a conocer, a impresionarse con lo extraño. Procedente del Pacífico sur y dada la actividad mercantil de esa región, desembarca en Islay para iniciar su aventura por el sur. Le impresiona la terrible situación de ese puerto, de gran actividad mercantil pero con su pueblo desordenado y de casitas precarias. Avanza guiado por un arriero y sus mulas, que lo lleva a Arequipa. Constata el desierto de la zona, lo agreste del territorio hasta que llega a Víctor, pueblo donde buscan un lugar cálido y agradable para pasar la noche y no lo encuentran. Por lo que deben pasar la noche finalmente en un tambo «y puedo asegurar que después de una marcha forzosa de trece horas, se duerme perfectamente sobre una manta y bajo un techo de cañas». Finalmente llega a la ciudad de Arequipa, alojándose como el viajero Lafond de Lurcy durante 1826 en la casa del principal comerciante francés de la ciudad, Santiague Le Bris. Según Flora Tristán este alojaba en su casa «a todos los viajeros de distinción que vienen al país» (De Sartigues - Botmiliau, 1947, pp. 4-5).

Admirado de las costumbres de los arequipeños describe con fineza sus reuniones de salón, las conversaciones con señoras y señores principales de la ciudad. Admira los bailes locales -el lundú, el mismis, el fandango español, los boleros- y señala desconcertado que «por nuestra fría y monótona cuadrilla los peruanos abandonen los lindos bailes nacionales» (De Sartigues - Botmiliau, 1947, pp. 15). Se detiene en admirar a las tapadas, y recorriendo los alrededores de la ciudad recoge los testimonios sobre la importancia del Misti, anota sobre los viñedos esparcidos por los márgenes del río Chili, ve las pulperías en los sitios de arroyos, donde la gente popular come ají y toma chicha. Reconoce que es agradable la chicha y recuerda que un extranjero lo debe beber pues ya internándose en la sierra es la única bebida que va a encontrar. También recorre los baños públicos, las iglesias y conventos, apreciando su decorado y a los santos principales.

Pero dado que su interés es observar y conocer paisajes y a la sociedad peruana pronto sale de esta ciudad y con un ciudadano inglés, se va para Puno. En el viaje descansa en tambos como los de Cangallo o de Apo. Los tambos son muy humildes, casitas de poca extensión con adobes y paja, camas de poyo en barro al medio de la pieza principal, que servían también como mesas -encima del cuál luego los viajeros extendían sus colchones o acomodaban sus ponchos-. Hacía mucho frio o viento debido a lo descuidado de su construcción. Según el vizconde si uno no traía sus provisiones consigo podía echarse a dormir sin probar bocado. En el camino ve vicuñas: «Pude disparar fácilmente sobre una que se alejó arrastrando la pata. Dejé mi mula para correr detrás de la vicuña; pero no había dado veinticinco pasos cuando se apoderó de mí un violento dolor de cabeza, me faltó la respiración, me sentí rendido de cansancio y me ví obligado a cesar en la persecución» (De Sartigues - Botmiliau, 1947, pp. 22-23). A veces descansa en haciendas, por ejemplo en la de Tincopalca, propiedad de un inglés. Luego va a Vilque, a conocer ese lugar famoso por su feria de mulas, que vienen desde Tucumán.

Llega a la ciudad de Puno, la visita, así como una mina de plata y luego se va a Bolivia, donde según propia confesión descubre el interés por las antigüedades americanas. De modo que de regreso a Puno, y luego de conocer el lago Titicaca y algunas de sus islas, visita las chulpas de Sillustani, en Atuncolla. Se interesa por las tumbas de las chulpas y luego se va a Lampa, en donde pernocta de forma agradable gracias a hospedarse en la vivienda de un médico y minero inglés, vivienda que la considera muy cómoda para los 
estándares de la sierra. Dadas las fechas (febrero de 1834) participa en la fiesta de carnavales de la ciudad, en medio de danzas con violines, arpas y tamborines. Anota que se utilizaba abundante alcohol en las calles y se echaba harina en la cabeza a la gente mientras se cantaban en las casas llantos y yaravíes en medio de gran jolgorio.

Prosigue su viaje luego al Cuzco y en su camino, en Urcos, se hospeda en la casa de un viejo noble español, con el cual comparten el gusto por la vajilla de plata y los vinos, y que le comenta lo difícil que es convivir políticamente en tiempos republicanos, con guerras y expoliaciones de todo tipo. Esta hacienda de Pacuta tenía una casa muy cómoda para el viajero, pues recuerda que en otras «en medio de la comida espléndidamente servida, siente uno que las gallinas le pican las piernas o los carneros se las muerden» (De Sartigues - Botmiliau, 1947, pp. 54-58).

Cerca de Andahuailillas visita el Sitio Arqueológico de Pikillaqta, que le llama la atención, y ya en el Cuzco se hospeda en la casa de un principal de la ciudad, que le tiene reservado un departamento en lo alto de su casa, por cuyas ventanas puede ver el movimiento de la Plaza de San Francisco, el mercado del Baratillo. Recibe muchas visitas y describe a los cuzqueños - se entiende, a las familias principales que conoce en los cuatro meses de estadía- como solemnes, circunspectos, de trajes oscuros, y a diferencia de los alegres salones arequipeños, con un trato social mínimo entre familias, que poco se visitan. Le da mucho crédito a la comida, excesiva para él en ají, hechas en ollas cubiertas; aunque aprecia mejor los ponches que las familias sirven y la alegría de las fiestas caseras cuando estas se dan. Tiene palabras de aprecio para las celebraciones de la Semana Santa de Cuzco, y se detiene en detallar la gran devoción que se tiene por el Señor de los Temblores, sobre todo durante su procesión por las calles, entre flores y hojas de rosas que las personan le echan. Durante su larga estancia cuzqueña «pude continuar mis paseos arqueológicos» y visita la cercana fortaleza de Sacsayhuaman, que la describe con bastante precisión (De Sartigues - Botmiliau, 1947, pp. 64-75).

Por último sale de Cuzco a Lima, al final de la época de lluvias, seguramente hacia junio o julio y se dirige con su comitiva de cargadores hacia ella, pero en Curahuasi, el cura que conoce «un anticuario» le fascina con sus relatos sobre Choquequirao y él, entusiasta por más aventuras, decide desviarse de la ruta a Lima hacia Mollepata, con cartas de recomendación al jefe de la posta de ese lugar, debiendo flanquear las cordillera, por entre la aldea india de Sorai hasta la hacienda de Huadquiña. Se magnifica de los nevados en su travesía, del Salcantay y el Soray, anotando sobre el poblado de este último «Se vivaquea (...) en medio de gallinas, pulgas y conejillos de Indias, cuyes, huéspedes obligados y queridos de todas las chozas de indios» (De Sartigues - Botmiliau, 1947, pp. 79-93). Asciende hasta las punas, cerca de los nevados, y desciende de nuevo, ahora en las zonas orientales, llegando a la hacienda de Huadquiña, donde se hospeda en la casa del propietario, un viejo conocido. Mirando el valle de Santa Ana, planean el viaje a Choquequirao. Conoce en este lugar la coca y los productos de los andes orientales. Mientras se preparaba la misión aprovecha para visitar Santa Ana y la misión de Cocabambilla. En Santa Ana asiste a la fiesta de la Cruces, en medio de chicha y bailes en honor de las cruces confeccionadas por los indígenas. Interesado porque hasta la misión de Cocabambilla han llegado pobladores amazónicos para participar en las fiestas, parte hacia las selvas, atravesando Echarati. Su contacto es fascinante y describe largamente las costumbres que observa, tan impactado queda que se va con ellos, los Antis, a sus tierras. 
Regresa finalmente a la hacienda de Huadquiña por Yanatili, hospedándose, en el camino, en la casa del alcalde de Lares, para aprovechar y visitar el sitio arqueológico allí existente; pasando luego por la hacienda de Huayru, donde su propietario peruano pero educado en París le invita a quedarse para la fiesta de San Antonio de su hacienda. Finalmente en Huadquiña ve como el hacendado y su primo, venido de otro lugar, están preparado una expedición en forma para Choquequirao, pues esperan descubrir tesoros. Quedaron en repartirse en tercios lo que se hallara. "Consentí, seguro de encontrar mayor cantidad de piedras, vasos y objetos de cerámica que montones de oro» (De Sartigues - Botmiliau, 1947, p. 98).

El viaje fue extenuante, entre lugares abandonados a la maleza, los insectos y huellas de lugares abandonados desde tiempos coloniales. Llegados a Choquequirao la maleza tupida les planteó esfuerzos serios en despejarlas y, mientras él tomaba apuntes y dibujaba, sus socios excavaban por aquí y por allá creyendo encontrar tesoros, pero nada hallaron. Al final solo se llevaron «algunos fragmentos de vasos y dos o tres topos de cobre» (De Sartigues - Botmiliau, 1947, p. 104). Por último se despide de ellos y regresa a Soray y enrumba al camino de Lima.

Se va hacia Abancay, donde asiste a la fiesta de Santiago, presenciando la corrida de toros y la fiesta donde indios y cholos, bebidos de chicha, participan corriéndose de los toros. Visita luego la hacienda cañera de Auquibamba, del cuñado del general Santa Cruz. En Chinchero asiste a la procesión de la fiesta de la Virgen de Loreto, y presencia otra corrida de toros, tan común en los Andes. Su descripción es fina y llena de detalles de la misma. Luego pasa por Huamanga, donde no se sorprende por las iglesias y conventos -en verdad en todo el viaje no se sorprende de ellas-, un grupo de principales le invitan a una trilla de trigo en una hacienda y luego de quince días parte a Lima. Aunque no tiene amigos reconoce la sencillez y calidez de quienes lo acogieron (De Sartigues - Botmiliau, 1947). Finalmente llega a Lima en las celebraciones de Nuestra Señora de la Merced, patrona de la independencia.

Recuerda la importancia del Día de los Muertos y va al Cementerio Presbítero Maestro y nos da detalles de la vida limeña en ese día. Nos describe las fiestas patrióticas por el 9 de diciembre en Lima, las corridas de toros y por último, su incursión a los baños de Chorrillos (De Sartigues - Botmiliau, 1947).

Así pues, con el vizconde De Sartigues estamos, no solo ante un viajero aristócrata y romántico del siglo XIX, sino claramente ante un turista aventurero, como los que existen hoy en día. Tiene los suficientes recursos económicos para ir donde su fascinación le alerte y se hospeda en cuantos lugares puede: desde tambos, pasando por haciendas de amigos hasta pisos confortables en ciudades. Además, a través de él podemos ver cómo el país tiene mucho que mostrar. Desde las chulpas de Sillustani, el lago Titicaca, los lugares arqueológicos del Cuzco, las selvas altas, hasta el gran sitio de Choquequirao.

Como más tarde hubo de reconocerlo Hiram Bingham, el vizconde fue el primer europeo moderno en llegar a la ciudad refugio de Manco Inca y Sayri Tupac, y su hazaña es digna de toda mención (Núñez, 1989).

Distinto será el caso de Flora Tristán. Como sabemos ella llegó a Arequipa, procedente de Francia, para reclamar la herencia de su padre fallecido, a pesar de ser hija natural. Se hospeda en una de las casas de la familia Tristán de Arequipa, y luego de estar unos meses en esta ciudad parte a Lima, por mar, donde permanece 
unas semanas más antes de regresar a Europa. En general, permanece en el país entre setiembre de 1833 y julio de 1834. Por lo tanto, no estamos ante una mujer interesada por visitar el Perú como destino sino solo frente a una viajera que llega al país para atender sus asuntos personales, pero que aprovecha para visitar algunos lugares de ambas ciudades. Su mala relación con la familia paterna le lleva, también, a una cierta visión negativa del país, salvo con las personas que le brindan algo de colaboración. El libro originalmente fue publicado en 1838 por la imprenta Arthurs Bertrand, Peregrinations d'une paria, y obtuvo un rotundo éxito literario, recibiendo diversos comentarios en la Revue de París de 1838 y 1839, e incluso una crítica negativa de Honoré de Balzac, que ayudó a encumbrar su obra.

Narrando su recorrido nos refiere que desembarca en Islay y se hospeda en la casa del director de Correos. Allí se ve azotada por las pulgas, a pesar de las prevenciones tomadas por sus anfitriones, partiendo al día siguiente con un grupo de amigos, en mula, hacia Arequipa. En Guerrera, descansa y come, durmiendo luego en el tambo que marcaba el fin de la pampa, aunque tuvo que lidiar igualmente con las pulgas. Al día siguiente, llegó al albergue y correo de Congata, donde le sirvieron un caldo y en una capilla le hicieron un lecho para descansar, siendo atendida como podría ser «en un hotel de las grandes ciudades de Europa» (Tristán, 2003, pp. 227-459). Hasta allí, llegará una comitiva familiar a buscarla y llevarla a la ciudad de Arequipa.

En Lima, tiempo después, se hospedará en la casa de la señora Denuelle, una antigua artista de nombre Mme. Aubrit, que vivía aquí desde 1826, casada con el señor Denuelle, que ya tenía este «hotel». Un hospedaje francés en Lima, donde había muchos otros viajeros -oficiales marinos y comerciantes- con quienes compartir conversaciones y experiencias. Le cobraron dos pesos por día, siendo la pensión «la más hermosa y mejor atendida de todas las que hay en Lima». La propietaria tenía un almacén anexo de mercaderías y tenía además una empresa de coches de pasajeros entre Lima y Callao. Su pensión tenía un comedor para 40 personas, sala de billar y jardín. Había mucha pulcritud, belleza y un servicio atendido por franceses e ingleses «de suerte que todo se hacía con mucha prontitud y limpieza» (Tristán, 2003, pp. 465473). Su hotel era como el Hotel Brunet de Londres, según Flora.

Hará un tour por la ciudad. Visitará la Catedral, San Francisco, el monasterio de La Encarnación, o el edificio de la Inquisición en donde aprecia los calabozos y afirma que hay un gabinete de historia natural y un museo con cuatro momias, conchas, pájaros y muestras de minerales, sin estatuas, y hay en materia de cuadros cuatro «mamarrachos» sin siquiera estar en bastidores, aunque reconoce que Mariano Eduardo de Rivero, su director, hace lo mejor que puede, pues no hay presupuesto. Visita el Congreso y observa los debates, también visita Palacio de gobierno, el Teatro, y va a las corridas de toros de Acho, mostrando su rechazo al arte taurino. Las mujeres, consideradas por ella como superiores a los hombres de Lima en inteligencia y en fuerza moral, las analiza en detalle, deteniéndose por cierto en sus sayas y mantos. Como se ve hace el clásico recorrido por los edificios de Lima y narración de sus costumbres.

Habla de las fiestas religiosas, del Paseo de Aguas y la Alameda, que son recorridos por calesas los días domingos o feriados por la tarde. Se parece «al boulevard de Gante». Como justo, además, llega a fines de junio de 1834, alcanza a ver la fiesta de Amancaes, el San Juan de ese año, «especie de Longchamp», con gente en calesas, a caballo o a pie yendo a la pampa, donde «se arman tiendas en las cuales se venden refrescos 
y se ejecutan las danzas más indecentes». La gente puede quedarse allí hasta la noche. Finalmente, va a Miraflores, sitio de placer, pasa por Barranco y llega a Chorrillos, con sus rústicas casas para veraneantes, lugar de placer e «intrigas amorosas, políticas y demás», aunque asevera es el sitio más árido y desagradable de la costa, «para mi gusto». Llegó invitada por la familia Izcue, que había alquilado una casa. Nota como la gente se baña en el mar y luego se enjuaga en los chorrillos de agua dulce que caen por los acantilados. Le fastidia la precariedad de estos baños «el lugar por lo demás, es muy incómodo para bañarse. Se podría hacer con poco gasto baños tan agradables como los de Dieppe» (Tristán, 2003, pp. 484-595). La comida es muy cara, la arena negra, las casas llenan de vejeces, «el lugar más detestable que he encontrado en mi vida», aunque reconoce que ya tiene como 800 viviendas y la gente se divierte jugando, fumando o en los bailes nocturnos que se dan. Finaliza su incursión visitando la hacienda azucarera Villa, de la familia Lavalle.

Así tenemos, a mediados de la década de 1830, dos visiones contrapuestas: la de un auténtico turista como De Sartigues, dispuesto a conocer, apreciar lo desconocido, no comparar sino buscar las originalidades; un viajero empedernido. Y por otro lado, una viajera que enjuicia y compara constantemente. De alguna manera representan el momento de transición en que se vive. De un lado el país de Choquequirao, de los andes y de las chulpas de Sillustani. Del otro, las imágenes urbanas recurrentes. También, a veces, una visión idílica del país y una visión descarnada, de denuncia de lo que a menudo se encuentra.

El suizo Johann Jakob von Tschudi, que en dos oportunidades estuvo en nuestro país y visitó algunos de sus espacios con el esmero de un científico y naturalista, tiene una visión amplia de la cobertura geográfica a diferencia de Tristán pero menos romántico que De Sartigues y muy descarnado en sus relatos. Su primer viaje al Perú aconteció entre 1838 y 1842, y le permitió visitar el norte chico, la sierra y selva central e Ica; y en la segunda vez, en 1858, visitó solo la costa del sur, Puno y luego Lima. Del primer viaje extraería material que le permitiría publicar sus Bosquejos de viaje al Perú en 1846, interesándose tanto sobre el país que luego en 1851 editaria con Mariano Eduardo de Rivero en Viena su famosa Antigüedades Peruanas, en dos volúmenes, obra luego vertida al francés e inglés.

En sus Bosquejos describe la ciudad de Lima, con un sentido clásico, mostrándonos los lugares ya conocidos, aunque también nos refiere del sitio de Pachacámac (Tschudi 2003). Describe su viaje por el norte chico, donde visita la fortaleza de Paramonga, y su viaje al sur chico. En el segundo tomo, dedicado a la sierra, señala que los caminos son muy dificiles, por las condiciones geográficas y el clima, y narra su viaje por la sierra central. Habla de un tambo delante del pueblo de San Juan de Matucana y refiere que los tambos, que son lugares que prestan alojamiento y a veces comida, no son mejores que los de Lima. Si en Lima es un cuarto vacío con una silla, allí es un cuarto de tierra sin nada y hay que acomodar el colchón que uno trae. Es preferible dormir afuera si el clima lo permite, que entre indios, negros, perros y chanchos. Dice que allí siempre se consigue chicha o aguardiente pero muy pocas veces comida, por el miedo de los indios a que no les paguen, pues «los oficiales los estafan» a menudo. En las zonas altas reconoce hay que «tomar medidas drásticas» para cambiar este comportamiento de los indígenas. Lo achaca en general a las guerras que han provocado la desconfianza y la violencia. Aunque en Viso, antes de San Mateo, reconoce que «el viajero encuentra un lugar más o menos aceptable para pasar la noche y suficiente comida para los animales». Sin embargo, en San Mateo «la hospitalidad (...) parece ser desconocida (...) Se muestran desconfiados, poco amables y burdos 
frente a los forasteros» (Tschudi, 2003, pp. 173-225). Apenas un viajero llega al pueblo aparece el alcalde para pedir pasaportes. Si no se los entrega puede ser detenido y maltratado. Pero como son analfabetos se les puede engañar: él lo hizo una vez con un simple papel escrito.

Luego nos habla del tambo de Acchahuari, un tambo muy frecuentado por los viajeros. Reconoce que muchas veces pernoctó en ese lugar, pero nunca hasta el día siguiente, a pesar del clima inclemente. Una «vieja india asquerosamente sucia hacía de anfitriona» acompañada de su hija y nietos. Su chupe de papa, ají y agua solo se le encontraba sabor después de hambre feroz tras el trajín del viaje. Pero «si se inspecciona este plato más de cerca, se suele encontrar en su superficie algunos pequeños animales luchando por su vida, que habían caído en la olla de los vestidos tiesos de suciedad de las mujeres». Para dormir la india les tendía una frazada de lana en el piso húmedo y los viajeros recibían su piel de oveja. Uno y otro estaban cubiertos de piojos y aunque uno saliera a la puerta del albergue tapándose con sus propias frazadas de la silla de montar, los animales igual les caminaban, pues estaban en el piso y en las paredes. Su crítica es pues feroz a la situación de los albergues de viajeros en el país, a su infraestructura y a la comida ofrecida. Aunque, también, reconocía que no todos los tambos eran iguales. En La Oroya, cerca de un puente, se encontraba «un tambo razonablemente limpio», donde vivía el puentero. Se pagaba dos reales por persona y animal, y se encontraba cebada en abundancia.

Tschudi (2003) le dedica una larga descripción, en varios capítulos, a la sierra central, la naturaleza, recursos, clima, los hombres, las minas, las fiestas. Describe las fiestas religiosas con mucha prodigalidad y el convento de Ocopa. También habla largo de la selva central y del cerro de la Sal.

Finalmente, nuestra descripción de los viajeros de la época no estaría completa sin el texto de Adolfo de Bormiliau, vice cónsul de Francia entre 1841 y 1848 en el Perú, que publicó su relato en la Revue des Deux Mondes (1 de abril y 1 de junio de 1850). Tiene su pluma una visión dramática del país, reconociendo que aparte de unas pocas ciudades, es un país despoblado, difícil y árido para aquéllos visitantes extranjeros que se atrevan a recorrerlo:

No se encuentran (...) mas habitaciones que las oficinas del correo, aún bastante escasas (...) No hay que buscar caminos trillados, es menester contentarse con algunos senderos mal trazados (...) Por la noche tampoco se debe esperar otra posada que las pobres chozas indias y no siempre hay la seguridad de encontrarlas al final de una jornada de fatigas. (De Sartigues - Botmiliau, 1947, pp. 138-180)

Aunque asevera que los peruanos son hospitalarios con los pocos viajeros que en general se movilizan por el país.

Su relato es casi una guía para el europeo visitante, pues constantemente hace referencia a lo que puede o no encontrarse. Así, en su texto hace un recorrido por la ciudad de Lima, entra a las iglesias y los conventos, visita el museo «muy pobre, salvo en antigüedades de los indios». Recuerda que entre el Callao y Lima hay muchas tumbas y templos prehispánicos, lo que le da a los alrededores de estas ciudades un interés patrimonial especial. Pero su mayor deleite es describir las fiestas de Amancaes, a la gente asistir, bailar zamacueca, beber pisco, «el cognac del Perú», y chicha en abundancia (De Sartigues - Botmiliau, 1947, pp. 184-194). 
Apreciar a la gente en su conjunto es de sumo placer y para ello aparte de Amancaes resalta las procesiones religiosas en Lima, donde se puede distinguir a las mujeres de saya y manto, muy coquetas. Dice que a un extranjero se le abren fácil los salones de las casas de las familias ricas de Lima, y las describe con paciencia, sobre todo las de las familias coloniales, venidas un tanto a menos tras la independencia.

«El europeo que se decide a visitar la parte montañosa del Perú debe esperar toda clase de fatigas y de privaciones» anota luego advirtiendo con lo que puede encontrarse. Son regiones casi desiertas dice, donde apenas existen algunas chozas indias aquí o allá. Luego de un día a caballo se encuentra apenas una «mala oficina de correo (posta) en donde pasar la noche». Son chozas recubiertas de paja con una puerta a medio cerrar con piel de buey tendida sobre un marco de madera, y en el interior, se amontonan arrieros y viajeros, alrededor de un poyo de adobe de algunos centímetros de alto que sirve de lecho y a veces, al centro, otro que sirve de mesa donde se sirve la comida que ha traído o le sirven chupe «si por casualidad se encuentra en la posta la carne seca y las papas». Así pues, no solo hay que llevar consigo caballos sino «también el lecho si uno no quiere dormir en el suelo desnudo, pan y vino y hasta la vela que debe alumbrar por la noche en el desgraciado rancho que uno se detiene». Al describir a los indios guías que se debe contratar, atestigua que están hechos para estas duras condiciones, con su vestido de poncho que le sirve de abrigo y de manta. En general, recomienda atravesar las montañas entre abril y diciembre, para evitar las lluvias y el deshielo fangoso (De Sartigues - Botmiliau, 1947, pp. 196-197).

Sin embargo, su relato cambia cuando describe su viaje a Pasco y a la feria de Vilque. Por sus líneas pasan la límpida noche de la sierra de alturas, con estrellas y soledad magníficas, las monumentales montañas y las tormentas inigualables, pero habla con pena de las chozas de los campesinos de altura en lo que se alojó y su pobre posada, y su chupe «único plato, según creo, de la cocina indígena» (De Sartigues Botmiliau, 1947, p. 201), hecho con ají, papas, maíz y algunas carnes de carnero o llamas secas al sol. Habla de una fiesta religiosa en Cerro de Pasco, con muchos bailes, comida y alcohol durante tres días. Luego nos habla de que en Pentecostes, en Vilque, Puno, se produce la famosa feria. Dice, que durante dos semanas unos diez o doce mil viajeros se concentran en esa feria, procedentes del sur andino peruano, Bolivia y Tucumán. Aunque «no hay en el interior de la América del Sur hoteles donde uno se pueda alojar», si los hubiera en Vilque no bastarían, con tanta gente ${ }^{1}$. Él llegó, tomando sus precauciones, pues sabía que «cuando se viaja por el Perú es preciso proveerse de cartas de presentación» y así uno encuentra la más amable hospitalidad de los residentes. Ahora bien, si uno es extranjero no necesita en verdad de estas cartas. «Todas las casas se abren enseguida». En Vilque se hospedó en casa de un principal del lugar. Narra, que estando allí unos viajeros llegaron a la casa y la esposa del dueño les hizo entrar solo con decir que hacían negocios con él, haciéndoles un sitio en la mesa para comer (Informes de los Cónsules Franceses, 2015, p. 59).

A todos se les ofrece un dormitorio común donde tirar sus respectivos colchones, pero al día siguiente uno lo debe enrollar y así dejar libre los espacios para los que vengan. En la hora del té o en las comidas compartidas entre chupes, asados, frituras o dulces, recién uno conoce a los otros que están hospedados (De Sartigues - Botmiliau, 1947).

1 El Cónsul Arnaud Lemoyne visitó en 1846 la feria de Vilque. Arguyó que el pueblo tenía 2 mil habitantes, pero en Petecostés recibía de 25 a 30 mil personas durante los 12 o 15 dias que duraba la feria . 
«Una excursión por la sierra no está completa, sin embargo, sino cuando al regreso uno se dirige al Cusco», dice sin titubeos y está ya claro lo que hasta el día de hoy turistas u hombres de negocios realizan al ir hacia Cuzco aunque no esté en sus planes inicialmente. En su camino luego de la feria de Vilque se detiene en Lampa, Pucará o Santa Rosa, anotando la noche que pasó en Agua Caliente, «pobre posta» cerca de Maranganí. Luego de atravesar otros pueblos finalmente llega a la ciudad del Cuzco, recorre sus calles, visita sus edificios más connotados, resalta las bases prehispánicas sobre las que ha construido la ciudad de españoles, se admira de la maestría de las construcciones, entre cuyas piedras desea meter una hoja de cuchillo pero no puede. Visita Sacsayhuaman, y finalmente se pregunta cómo pudieron construir esas edificaciones y reconoce que era una civilización infinitamente superior a lo que uno piensa (De Sartigues - Botmiliau, 1947, pp. 209-212). Cuzco en esa época era, por cierto, resaltado por su propia elite como espacio dónde se fundía el pasado monumental con el presente, y este orgullo se expresaba a cada instante (Valdez y Palacios, 1971).

Así pues en Botmiliau, que escribe en la Revue des Deux Mondes para un gran público interesado por los viajes y el conocimiento, hay un afán de servir como un guía, un consejero, advirtiendo de los escollos a encontrar -que tal vez vuelva más fascinante el país- pero mostrando también sus grandes atractivos ${ }^{2}$. El Perú como lugar de destino, para los negocios y las oportunidades, pero también para el ocio.

\section{Una infraestructura que se abre paso}

Mientras tanto los hospedajes, no en provincias, sino en la ciudad de Lima iban progresando a ritmo vertiginoso. Hacia 1815 habían diversas fondas como las de las calles de La Merced, Mantas, Animas, Pescadería o Abajo el Puente, o la del Caballo Blanco, en la calle Lártiga. Aunque, al parecer si seguimos a Von Tschudi y otros viajeros, estos eran «sucios y malos», sin embargo, su número fue creciendo, por la demanda de alojamiento y comida propias de una ciudad en crecimiento. Para 1839 había 16 fondas, 10 posadas, 82 chinganas, 32 picanterías y 96 chicherías (Córdova y Urrutia, 1992 [1839], pp. 40-41).

Las áreas de hospedajes de estas fondas eran mejores que las de los humildes tambos, dispersos por la periferia o el centro de la ciudad de Lima. Con el tiempo, para cubrir la creciente demanda, se animaron también algunos cafés a tener alojamientos y se convirtieron en fondas, como le ocurrió en 1819 al café de Santo Domingo que tenía algunas habitaciones altas, en las que se alojaban forasteros y transeúntes. Luego le siguieron otros cafés, como el de la Calle de Espaderos, que se convirtió en la Fonda León de Oro; el que estaba en la calle de las Ánimas; o el de la calle de Mercaderes, que se llamaría La Bola de Oro entre 1830 y 1860 (Holguín Gallo, 2013, pp. 158-161). Incluso, algunos tambos, para adaptarse a esos cambios, se modernizaron y se convirtieron igualmente en fondas o alojamientos, aunque de nivel más económico: según el diario El Comercio de 1844 uno de los lugares de hospedaje «que pueden tener mejor ubicación» es el «El Tambo de Polvos Azules (...) en el centro de Lima, en medio del comercio, cerca de los tribunales (...) con comodidades interiores, aseo y orden producto de recientes refacciones» (García, 2015, p. 81).

2 Hay que remarcar que la revolución editorial europea amplifica los efectos de estos textos y los lectores estimulan para que se deje una simple descripción de costumbres y se plantee otras percepciones vinculadas a una invitación a conocer. 
Con el tiempo algunas fondas, dirigidas a un público más selecto, terminaron convertidos en Hoteles -un concepto inexistente en Lima antes de 1840, atribuible a un lugar más confortable, relacionable a un estilo de vida y gusto burgués o aristocrático-, con comedor anexo, sofisticado e inasequible al bolsillo de cualquiera. Por ejemplo, en 1843 la Bola de Oro tenía uno de los mejores comedores, junto a la Fonda de Coppola -que databa de 1828, en la calle de la Merced, luego convertido en el Hotel Americano, trasladado a la calle de Espaderos-, famoso por sus churrascos. Se decía, hacia 1848, que los mejores hospedajes eran estos dos, la antigua fonda Italiana - que no hay que confundirla con una fonda que existió hacia 1820, de Luis Peschiera-, la de Morin (en la calle de Botoneros), la Victoria, Bola de Plata, el café Reyes y el Maury (entre las calles Bodegones y Villalta). Hacia 1846 la Bola de Oro ya se publicitaba como Hotel en un aviso impreso en periódicos, en castellano, y desde 1847 anunciaba que tenía un comedor abierto y permanente.

En cuanto a la fonda de Coppola, su origen estuvo en el inmigrante napolitano Coppola que llegó a Lima en 1806 como cocinero del virrey Abascal, y que luego de la independencia estableció una fonda que duró hasta la década de 1840. Ubicada en la calle Espaderos, con el paso de los años se transformó en hotel tomando el nombre de Hotel Americano, permaneciendo operativo hasta cerca de 1929 (García, 2015).

Caso similar fue el del Hotel Maury. Sus orígenes estuvieron en la famosa Fonda Francesa de nuestra ya señalada Carolina Aubé de Denuelle, en el cual se hospedó Tristán y otros viajeros, con su salón de cuarenta cubiertos, su atención con criados extranjeros -en 1824 el reverendo Hugh Salvin decía que tenía 28 habitaciones, ubicado en su nuevo local de la calle Valladolid, tras estar en La Merced-. En 1838 se vende la fonda y lo compra Pierre Maury, conocido empresario, quien le hace mejoras y empezará a conocerse como Hotel Francés y luego Hotel Maury. Decía el marino francés Max Radiguet, al hospedarse en la «Fonda Francesa», que Maury era un «bueno y digno compatriota establecido en Lima desde hace años» (Radiguet, 1971, pp. 15-25).

Se le conoce pues como hotel para la década de 1840, según avisos publicados en El Comercio y El Correo del Perú, aunque en francés o inglés, pues en castellano se hacían llamar todavía posada (Holguín Gallo, 2013, pp. 165-166) ${ }^{3}$.

En 1850 el Hotel Maury con el Hotel Morin eran los únicos hoteles franceses en Lima, según el cónsul Letellier (Holguín Gallo 2013, p. 170). Este otro tomaba su nombre de Fréderic Morin, residente desde 1828, cuya Posada de los Baños Tibios se convirtió en Hotel de los Baños Tibios y luego Hotel Morin. En el Portal de Escribanos ofrecía baños tibios y de vapor, café, mesa redonda, billar y comedor, entre otros. Entre 1842 y 1843 competía con el Hotel (Posada) y Café de la Marina, del Callao, de Juan Howell -el cuál era también copropietario de la Fonda Inglesa de la calle Plateros-, que tenía baños tibios, confitería, máquinas de agua de soda y de ginger beer, según avisos de El Comercio. La comida que ofrecían ambos hoteles eran de lo mejor y se gastaban mucho dinero quienes usaban sus servicios, comparado con el medio real que se gastaba por plato en las fondas humildes de Lima y los cuartillos por otras delicias.

3 Los extranjeros, como se ha visto llamaban Hotel a muchas fondas - Lafond de Lurcy decía en 1822 que había en la periferia de la ciudad un hotel llamado «del Perú»-. Esto no quiere decir que la palabra hostal no existiera entre nosotros. En un auto contra extranjeros en el siglo XVIII (AGN. Consulado GR2, caja 17, doc 734) se dice que en Lima hay «fondas, hostales, bodegones y cafeterías» (Holguín Gallo, 2013, p. 30). 
Finalmente, también era un hotel la llamada fonda y café Posada Nacional de la calle Palacio, que según El Comercio de 1840 tenía una sala específica para que las mujeres pudieran acudir a consumir helado, sus habitaciones tenían balcón a la calle, eran amobladas y aseadas a precios cómodos, siendo un establecimiento de los más concurridos con una comida exquisita y con la presencia de orquestas y recitales, según informaciones de ese diario y de La Bolsa. Tuvo diversos dueños entre 1840 y 1843 (García, 2015).

Así como en Europa, donde desde los mesones del siglo XVIII partían diligencias, pues se encontraban en el centro de las ciudades y disponían de establos y de alquiler de caballos, acá también la fonda de Coppola brindaba el servicio de transporte de pasajeros hacia Chorrillos y viceversa, sobre todo en fines de semana, según información recogida por los periódicos La Bolsa de 1841 o El Correo Peruano de 1845; igual ocurría con el Hotel de La Bola de Oro en la que se vendían helados y ofrecía servicios de alimentos y bebidas, banquetes, mesa redonda y café, y se ofrecía el servicio diario de coches para el puerto del Callao, según igualmente el diario El Comercio de 1846 (García, 2015). No debemos olvidar que antes de ser Hotel Maury, Carolina Aubé de Denuelle tenía un servicio de coches entre Lima y el Callao, probablemente desde la Fonda Francesa.

Con los años, otras fondas prosiguieron en su distinción como hoteles a diferencias de los que siguieron denominándose posadas o tambos. Por cierto, los tambos no desaparecieron, y comerciantes y otros forasteros con menores recursos lo utilizaban de manera asidua. En el año 1839 existían 14 tambos en la ciudad (Córdova y Urrutia, 1992 [1839]). De entre ellos, eran conocidos los tambos de Huamanga (en el actual jirón Dos de mayo); el tambo de Polvos Azules, cerca de la Plaza y lugar de descanso de muchos comerciantes -que luego evolucionó a fonda-; el tambo de Mesón Blanco en el actual jirón Huancavelica; el de Tambillo; el tambo de Belén; el tambo de La Legua, camino al Callao; y muchos otros en los distintos barrios (García, 2015).

La realidad de Lima era entonces de evolución en los servicios de alojamiento, con algunas limitaciones. Empero, si bien en otras ciudades y lugares del país estos servicios no tenían ese cierto dinamismo en su desarrollo, no quiere decir que no existieran. En otras ciudades del país habían muchas fondas y tambos, aunque los primeros no evolucionaran hacia el concepto de hotel. Estos mesones o fondas existían en todas las ciudades grandes, como Cerro de Pasco, según hemos visto; Huamanga, en la calle justamente de Mesones; o en Arequipa, Trujillo o Cuzco. Igualmente tambos había regados por todos los caminos, como se sabe, y en las periferías de las ciudades, como es el caso de los tambos San Lázaro o Tambo de la Cabezona, junto al puente Bolognesi, en Arequipa, o el tambo del puente a la entrada de Huamanga; o los tambos cercanos a la ciudad del Cuzco, pero también los había en la ciudad misma como el tambo de los Jesuitas de Arequipa, o Tambo y Tambo Chico en Huamanga. En Arequipa había hacia 1820 siete tambos urbanos: del Bronce, de la Quiteña, de Ballón, de San José, de Juan Isidro Zuñiga, de Bernardes alias de Malaruna y de Oyanguren. En Cuzco sobresalían el tambo de Montero, en la calle Saphi, o el tambo de San José, cerca de la calle de San Agustín (García, 2015). Ya sabemos que sin alojamiento no podemos hablar de servicios turísticos, y estos lugares vivían también un proceso de desarrollo. 


\section{Conclusiones}

Así pues, conforme nos acercamos a mediados del siglo XIX, el país es testigo de cambios significativos. Por un lado, una fijación de los destinos turísticos para el extranjero o el propio viajero peruano, pero con intereses por la observación y el deleite: no sólo los existentes lugares o espacios de las diversiones públicas que ya practican los habitantes locales -por ejemplo, en Lima o el Cuzco- sino también los lugares que eran presentados «a los foráneos»: sitios arqueológicos o lugares naturales, existiendo a veces guías eventuales para ello. Por otro lado, desde el país mismo, por esta y por razones más amplias, se es testigo no solo de una transformación en la infraestructura de hospedajes o de comidas; sino también en un lento cambio en la mentalidad de las propias elites sobre la importancia de estas diversiones o de estos lugares varios de interés. En todo caso, son las primeras señas de hechos que en los años siguientes se presentaran como más evidentes. José María Blanco, sacerdote que acompañó a mediados de la década de 1830 al viaje del presidente Luis José de Orbegoso por el sur del país, nos dejó una crónica fina con descripciones de fiestas y algunos lugares de diversión en Huamanga, Cuzco o Arequipa: la Semana Santa, la fiestas del Corpus Christi, el Señor de los Temblores, así como templos y otros edificios patrimoniales que pasaron frente a sus ojos (Blanco, 1974). La Estadística de Córdova y Urrutia, empresa privada, por su lado incorpora por ejemplo, en una sección «De los lugares de recreo», una descripción de los lugares y espacios para las diversiones limeñas (Córdova y Urrutia, 1992 [1839]). Claramente se iba tomando conciencia de la importancia de las diversiones y el ocio en el desarrollo nacional ${ }^{4}$.

Pero nuestro interés ha sido sobre todo comprender la naturaleza del turismo embrionario vigente en el Perú hasta la década de 1840 aproximadamente. Y el contraste con lo que estaba ocurriendo en Europa, comprendiendo que son los mismos desarrollos existentes entre el centro del mundo y los países de la periferia, entre el norte y el sur. Ciertos lugares que se desarrollaban lentamente para los ojos foráneos, un turismo concentrado en sectores altos, enormes dificultades en infraestructuras y servicios - caminos, hospedajes, comidas- y posibilidades de desarrollo que se iban vislumbrando -con evoluciones lentas en algunos servicios. Las primeras décadas del siglo habían superado una actividad concebida y vinculada con el ocio aristocrático, que caracterizaron los siglos previos y particularmente el siglo XVIII, por un interés creciente en visitar, conocer y darlo a conocer. Aunque luego, a partir de 1840, los cambios acelerados del mundo del norte dejarían muy atrás a los países de la periferia del mundo, con nuevos conceptos de hospedaje, hostelería, servicios financieros, infraestructuras de transportes, etc. Las diferencias en el desarrollo capitalista, mercados de consumos muy amplios y abiertos, tecnologías, abrirían una profunda divergencia en el desarrollo turístico posterior. Pero hasta antes de esa fecha el mundo no era tan distinto aquí y allí. Algo que los estudios historiográficos en la materia no han destacado, planteando más bien una divergencia de raíz y constante.

4 En este artículo deliberadamente no hemos tratado sobre los Calendario y guía de forasteros, que por aquéllos años anualmente el Estado edita, o las guías de forasterios y de domicilios locales, pues estos tenían más bien el fin de informar sobre el funcionamiento del aparato del Estado y dar otros datos útiles, siendo su destínario no precisamente el viajero extranjero, aunque eventualmente pudiera leerlos. 


\section{Referencias}

Blanco, J. M. (1974). Diario de viaje del Presidente Orbegoso al sur del Perú. (Dos tomos). Lima: Instituto Riva-Agüero.

Córdova y Urrutia, J. M. (1992 [1839]). Estadística Histórica, Geográfica, Industrial y Comercial de los pueblos que componen las provincias del departamento de Lima. Lima: Entre Nous.

De Sartigues - Botmiliau (1947). Dos viajeros franceses en el Perú Republicano. Traducción de Emilia Romero y Prólogo y notas de Raúl Porras Barrenechea. Lima: Cultura Antártica S. A.

García, R. (2015). Aproximación al Estudio de la Evolución del Espacio de Hospedaje en el Turismo Peruano (Pro-manuscripto). Lima: Universidad de San Martín de Porres.

Hall, B. (1971). El Perú en 1821, en CDIP. Colección Documental de la Independencia del Perú, XVII-1, 195-268.

Haigh, S. (1967). Bosquejos del Perú (1825-1827). En A. Tauro del Pino, Viajeros en el Perú Republicano. Lima: Universidad Nacional Mayor de San Marcos.

Holguín Gallo, O. (2013). Cafés y fondas en Lima ilustrada y romántica. Lima: Universidad de San Martín de Porres.

Humboldt, A. V. (2004). Mi viaje por el Camino del Inca (1801-1802). Antología. Edición y prólogo de D. Yudilevich L. Santiago: Editorial Universitaria.

Informes de los Cónsules franceses (2015). Informes de los Cónsules franceses en Lima, 1842-1877. Edición de Jaime Urrutia. Lima: Instituto Francés de Estudios Andinos e Instituto de Estudios Peruanos.

Khatchikian, M. (2000). Historia del Turismo. Lima: Universidad de San Martín de Porres.

Lafond de Lurcy, G. (1971). Remembranzas de Guayaquil (1822), Lima y Arica. CDIP, XVII-2, 83-

185. Lesson, R. P. (1971). Situación del Perú en 1823. CDIP, XVII-2, 339-401.

Mathison, G. F. (1971). Residencia en Lima entre abril y mayo de 1822. CDIP, XVII-1, 275-

318. Mellet, J. (1971). Impresiones sobre el Perú en 1815. CDIP, XVII-1, 79-117.

Miller, G. (1975). Memorias del general Guillermo Miller. Estudio preliminar de P. Cayo Córdova. Lima: Arica S.

A. Núñez, E. (1989). Viajes y viajeros extranjeros por el Perú. Lima: CONCYTEC.

Proctor, R. (1971). El Perú entre 1823 y 1824. CDIP, XVII-2, 187-338.

Radiguet, M. (1971). Lima y la sociedad peruana. Lima: Biblioteca Nacional del

Perú. Roquefeuil, C. de (1971). Lima y Callao en 1817. CDIP, XVII-1, 119-144.

Stevenson, W.B. (1971). Memorias sobre las campañas de San Martín y Cochrane en el Perú. CDIP, XVII-3, 73-338.

Tauzin-Castellanos, I. (2015). Gabriel de Lafond de Lurcy: un relato de viajes dedicado al Perú de 1821. En M. Cárdenas Moreno e I. Tauzin-Castellanos. Miradas reciprocas entre Perú y Francia. Viajeros, escritores y analistas (siglos XVIII-XX). Lima: Universidad Ricardo Palma, Université Bordeaux Montaigne y Embajada de Francia.

Tristán, F. (2003). Peregrinaciones de una paria. Lima: Centro Flora Tristán y Universidad Nacional Mayor de San Marcos.

Tschudi, J. J. von. (2003). El Perú. Esbozos de viajes realizados entre 1838 y 1842. Lima: PUCP.

Urry, J. (2004). La mirada del turista. Lima: Universidad de San Martín de Porres.

Valdez y Palacios, J. M. (1971). Viaje del Cuzco a Belén en el Gran Pará. Lima: Biblioteca Nacional del Perú. Walton,

J. (1983). The English Seaside Resort: A Social History, 1750-1914. Leicester: Leicester University Press.

Witt, H. (1992). Diario 1824-1890. Un testimonio personal sobre el Perú del siglo XIX. Volúmenes I y II. Banco Mercantil. 